ノート

温室内ポットおよび水耕検定によるサッマイモつる割病抵抗性品種間差の評価

山川博幹 1) ・島田 峻 2,3) ・ 藏之内利和 1) ・ 西中未央 4$)$

1) 農研機構作物研究部門, 茨城県つくば市, 干 305-8518

2) 茨城県農業総合センター農業研究所, 茨城県水戸市, 干 $311-4203$

3) 現: 茨城県農林水産部産地振興課, 茨城県水戸市, $\overline{\text { T } 310-8555}$

4) 農研機構中日本農業研究センター, 茨城県つくば市, † 305-8666

\title{
Evaluation of resistance to Fusarium stem rot in sweetpotato cultivars by pot and hydroponic culture
}

Hiromoto Yamakawa $^{1)}$, Shun Shimada ${ }^{2,3)}$, Toshikazu Kuranouchi ${ }^{1)}$ and Mio Nishinaka ${ }^{4)}$

1) Institute of Crop Science, NARO, Tsukuba, Ibaraki 305-8518, Japan

2) Agricultural Research Institute, Ibaraki Agricultural Center, Mito, Ibaraki 311-4203, Japan

3) Present address: Ibaraki Prefectural Government, Mito, Ibaraki 310-8555, Japan

4) Central Region Agricultural Research Center, NARO, Tsukuba, Ibaraki 305-8666, Japan

キーワード

サッマイモ，サッマイモつる割病，抵抗性，品種間差，ポット検定，水耕検定

\section{緒 言}

サッマイモ（Ipomoea batatas）は，種いもやつる苗等 の栄養体で増殖するため，種苗で伝染する病害が拡がり やすく（小川ら 1979），生産地に打いて甚大な被害を及 活すことがある。サッマイモつる割病は，サッマイモの 重要病害のひとつで, 糸状菌の一種, Fusarium oxysporum f. sp. batatas（サッマイモつる割病菌）によって引き起こ され, 污染された種いもや苗, 土壤等により伝染する. 苗が本病に感染すると, 植付後に下葉が黄化して萎れ, 芽頂の伸長が抑兄られ，茎が地際から縦に裂開する．著 しく発病すると枯死に至る。発病が軽微で塊根が得られ ても, 病原菌の感染によって塊根内部の維管束は褐変し, 外観上健全に見光る塊根を種いもとして利用すると苗伝 染の原因となる。生産現場では, 本病の防除法として, ベノミル剂等の農薬を用いた種いもや苗の消毒拈よびク ロルピクリン剂等の土壤くん蒸剤による土壌消毒が実施 されている.

良食味品種として昭和 50 年に育成された「ベニコマ チ」は，一度は千葉県等関東地方に広く普及したものの, 本病に極めて弱い（小川ら 1979）ことが判明したため,

編集委員 : 片山健二

2021 年 8 月 11 日受領 2021 年 9 月 21 日受理

2022 年 2 月 17 日 J-STAGE 早期公開

Correspondence: hy741220@affrc.go.jp
その後作付けが減少した．現在作付けされるサッマイモ 品種は本病に対して一定の抵抗性を有するものが多いが, 本病は $28^{\circ} \mathrm{C} \sim 30^{\circ} \mathrm{C}$ 高温で発生が助長される（小川ら 1979）ことから，近年の気候変動やマルチ被覆栽培によ る栽培環境の温暖化により, 発生増加が䯚念されている. 防除法についても問題は残されており，ベノミル剂によ る苗消毒の本病防除効果は完全ではない（小川ら 1979）. また，土壤くん蒸剤による土䁃消毒は環境への負荷が大 きく，いずれの防除対策も薬剤コストが必要である。さ らに，近年ではべノミル剂耐性サッマイモつる割病菌の 出現が確認された（島田ら 2017）ことから，高度抵抗性 を有する品種の導入が望まれている.

サッマイモ育種の現場に扔いては, 苗の切り口に病原 菌を接種後, 固場に植え付けるつる割病抵抗性検定試験 により育成系統のつる割病抵抗性が評価されている。し かし, 栽培中の気象条件等の変動により安定した結果が 得られないことがあるため, 通常複数年試験を実施して 結果を総合的飞判断して抵抗性が評価されている (Katayama et al. 2017)。一方，通年実施可能な温室等で の抵抗性評価が試みられている。 小川ら（1979）は，サ ッマイモ苗の切り口をつる割病菌懸濁液に浸漬した後に 鉢植えし，枯死状況を調査することにより，抵抗性を評 価した．本法では，人工的に作成した污染戋場への植え 付け試験よりも病徴が顕著に現和，抵抗性の品種間差を より詳細に評価することが可能になった。同様の方法に より, 北海道に打ける品種の抵抗性も評価されている 
（堀田・高濱 2014）。この他に，水を入れた試験管に病原 菌の懸濁液を針接種した苗を挿苗する方法（小川1988） や，切り苗を病原菌懸濁液中でそのまま培養する方法 （Yang et al. 2018, Paul et al. 2020）も実施されている. こ れらの方法では 2 週間程度で抵抗性を評価することが可 能である。一連の研究により, 従来品種の抵抗性が明ら かとなっているが，近年育成された品種の屋内検定法に よる詳細な抵抗性は不明である。

本研究では, 近年育成された品種のらち, 病害抵抗性 を備兄るとされるものについて，つる割病抵抗性を従来 品種と比較することを目的として, 主要な 10 品種の抵抗 性を, ポット検定沶よび水耕検定により体系的に評価し, 評価結果を品種育成試験で実施された固場検定結果と比 較した。

\section{材料および方法}

サツマイモ供試品種は, 平成 29 年度作付面積上位 5 品 種の「コガネセンガン」,「ベニアズマ」,「ベにはるか」, 「高系 14 号」,「シロユタカ」（農林水産省 2019）に加え て，小川ら（1979）により抵抗性弱とされた「ベニコマ チ」拈よび抵抗性強とされた「タマユタカ」, 近年育成さ れ病害抵抗性を有するとされる「からゆたか」（平成 26 年育成),「こないしん」(令和元年育成),「あまはづき (関東 144 号)」（令和 3 年育成）を合わせた 10 品種とし た。それ攵れ農研機構谷和原畑圃場（茨城県つくばみら い市）に扣いて健全なつるの先端 5 節程度もしくは中間 部位 3 節程度を採取し，暖房および天空の開閉で $20^{\circ} \mathrm{C} \sim$ $32^{\circ} \mathrm{C}$ 温度調節されたガラス温室に掞いて，〈みあい園 芸用育苗培土げんきくん 1 号（コープケミカル） $3 \mathrm{~L} を$ 入れたポットへ挿苗することで増殖した. $10 \mathrm{~cm}$ 以上に 伸長した増殖苗の先端を採取して，抵抗性検定に供試し た.

サツマイモつる割病菌は, 茨城県農業総合センター農 業研究所により茨城県行方市の現地発病株から分離され た $16 \mathrm{NGFo} 1$ 株を用いた. ポテトデキストロース寒天培地 を用いて $25^{\circ} \mathrm{C}$ で 7 日間前培養した菌叢を, ポテトデキス トロース液体培地に添加し， $28^{\circ} \mathrm{C}, 110 \mathrm{rpm}$ で 7 日間振 とら培湌した。得られた菌液を二層に重ねたガーゼでろ 過し， $1,500 \times g, 5$ 分間の遠心分離により胞子を回収し, 滅菌水で 2 回洗浄した後, 血球計算盤を用いて胞子数が 温室内ポット検定および水耕検定の場合 $1.5 \times 10^{6}$ 個 $/ \mathrm{ml}$, 圃場検定の場合 $1 \times 10^{7}$ 個 $/ \mathrm{ml}$ になるよらに滅菌水に懸濁 した.

ポット検定では， 1 試験区あたり冬季試験（令和 2 年 12 月 15 31 日に実施）で 5 本，夏季試験（令和 3 年 7 月 19〜29 日に実施）で 15 本の苗を供試し，苗の切り口 を胞子懸濁液に 30 分間浸漬することで接種した後, くみ あい園芸用育苗培土げんきくん 1 号 $3 \mathrm{~L}$ を入れたポット へ挿苗した。一方水耕検定では，1 試験区あたり冬季試
験で 4 本, 夏季試験で 12 本の苗を供試し, 苗の切り口を 同様に胞子懸濁液に 30 分間浸漬することで接種した後, 水道水 $50 \mathrm{ml}$ を入れた植物培養用 $125 \mathrm{ml}$ プラントボック スへ挿苗した. 以降, 上記の $20^{\circ} \mathrm{C} \sim 32^{\circ} \mathrm{C}$ 温度調節され たガラス温室に扣いて, 毎日灌水しながら, 病徴の進展 を調査した。発病程度は, 植え付け直後に発生する下位 葉の枯死を除いて病徵なし（指数 0 ）, 葉の黄変もしくは 枯死（指数 1), 茎あるいは茎頂の枯死（指数 2), 完全枯 死（指数 3）の 4 段階に分けて，個体数を記録し，試験 区全個体の指数の平均值を発病指数とした。冬季試験で は, 調査を開始した接種後 6 日目から, 完了した 16 日目 までの発病指数の合計值を累積発病指数とし，ポット検 定に打ける累積発病指数と水耕検定に扣ける累積発病指 数の平均值を総合発病指数とした. 夏季試験においては, 罹病性の「ベニコマチ」が概ね完全枯死した接種後 10 日 目に発病指数を調査し, ポット検定に扣ける発病指数と 水耕検定に打ける発病指数の平均值を総合発病指数とし た。また，夏季試験に扣いては，サッマイモつる割病菌 を含まない水中に 30 分間浸漬してからポットや水中に挿 苗する無接種無処理区を設け，供試苗が健全であること を確認した。

圃場検定については，16NGFo1 株を用いて充分な発病 が認められた 2018 年と 2020 年の結果を用いた。農研機 構谷和原畑圃場に扮いて 2018 年は 6 月 7 日, 2020 年は 6 月 10 日に, 試験区あたり 5 本の苗の切り口を胞子懸濁 液に数秒間浸漬して接種した後, 透明マルチを張った畦 へ株間 $15 \mathrm{~cm}$ で植え付けた。発病調査は罹病性の「ベニ コマチ」が枯死したのを確認した後, 2018 年は 7 月 11 日，2020年は 7 月 15 日に実施し, 次の基準で指数化し て評価した。指数 1 : 切り口からの菌の侵入による維管 束の褐変が基部から 1 節以内で止まっているもの, 指数 2 : 維管束の褐変が 1 節を超えて 2 節までで止まっている もの, 指数 3 : 維管束の褐変が 2 節を超えて地下部で止 まっているもの, 指数 4 : 維管束の褐変が地上部まで進 展しているが地上部の枯死は認められないもの, 指数 5 : 地上部が部分的に枯死しているもの, 指数 6 : 完全に枯 死しているもの. 年次による発病程度のばらつきを補正 するため, 得られた指数を基準品種（「タマユタカ」と 「ベニコマチ」をそれぞれやや強と弱とした）の数值と比 較して，抵抗性を判定した。

\section{結 果}

\section{1. 冬季試験}

冬季温室に拈けるポット検定扰よび水耕検定の結果を 図 1 に示す。抵抗性弱とされる「ベニコマチ」は極めて 高い罹病性を示し, ポット検定では接種後 2 週間以内に 供試した全個体が枯死した。同様に，「シロユタカ」と 「コガネセンガン」も迅速に病徵が進展し 2 週間で全個体 が枯死に至った。 これらの品種と比較して,「ベニアズ 

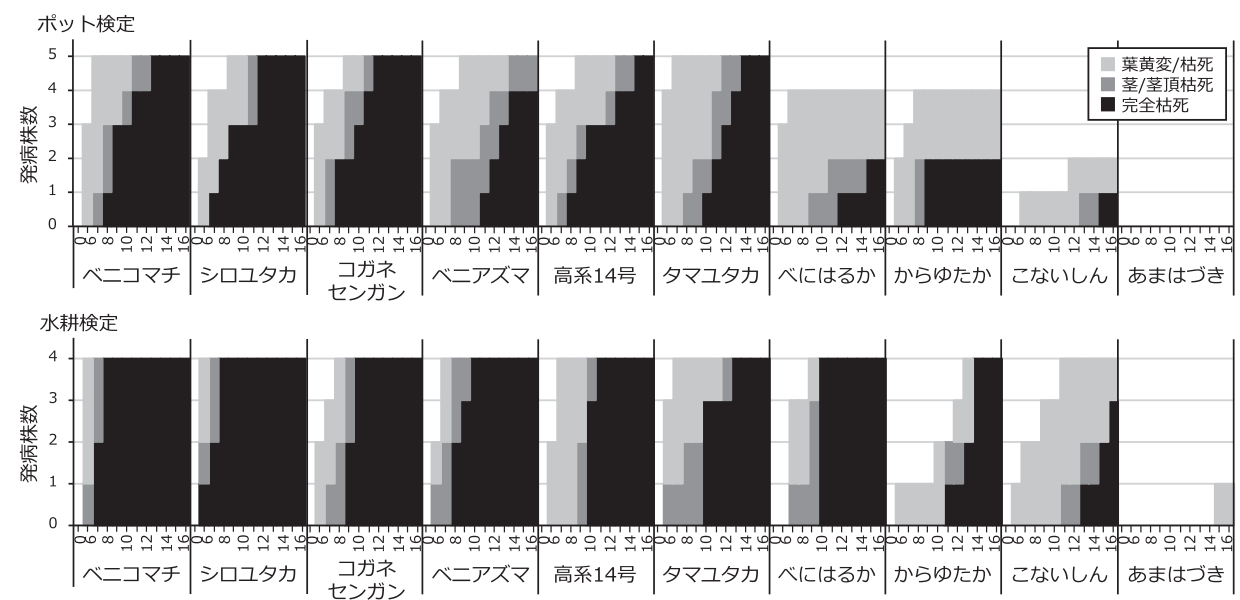

図 1. 冬季試験に拈けるサッマイモ 10 品種のサッマイモつる割病発病程度. 上段：ポット検定，下段：水耕検定. 横軸は接種後日数を示す.

ポット検定，接種後10日目

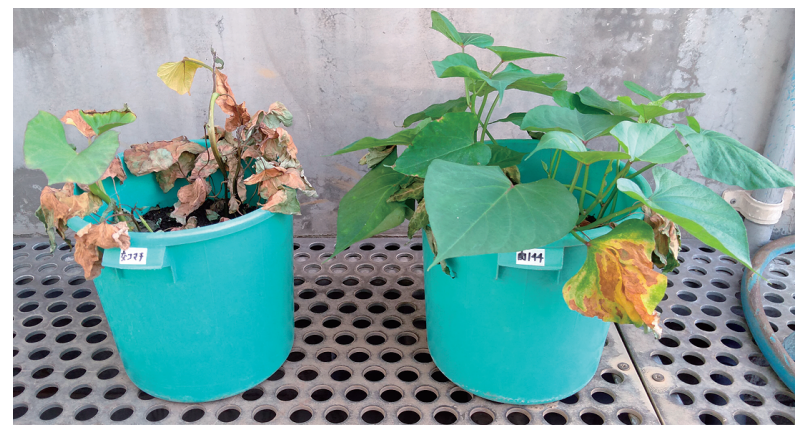

水耕検定，接種後10日目

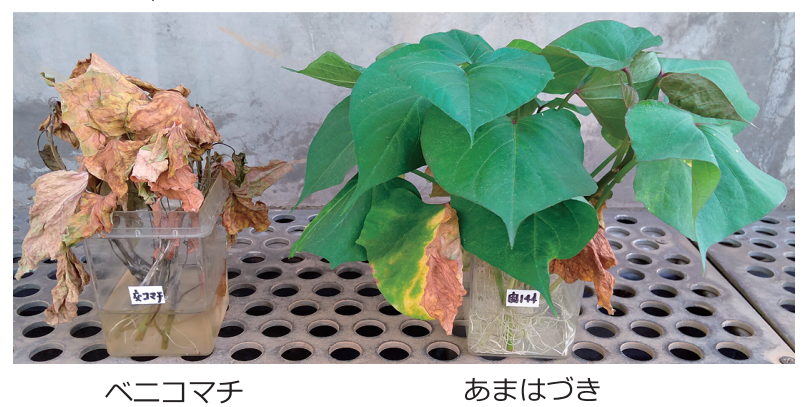

図 2. サッマイモつる割病発病状況.

上段：冬季試験ポット検定における接種後 10 日目，下

段：冬季試験水耕検定に打ける接種後 10 日目.

左：ベニコマチ，右：あまはづき.

マ」,「高系 14 号」,「タマユタカ」は病徵の進展がわずか に遅れる傾向が認められた。一方，「べにはるか」と「か らゆたか」は葉が枯调したものの，半数以上の個体が接 種後 16 日間枯死せずに生存した。「こないしん」は，葉 や茎の枯死も少なく，5個体中 4 個体が生存し，「あまは づき」では植え付け直後に最下位葉がわずかに枯れたの みで，16 日間全く病徵を示すことはなく，健全な成長を 続けた（図 2).

水耕検定では，ポット検定より病徵の進展が早く，「心゙ ニコマチ」と「シロユタカ」は接種後 8 日で全個体枯死 し,「コガネセンガン」,「ベニアズマ」がこれらの品種よ
表 1. 冬季試験検定結果から推定された各品種のサッマイモつ る割病抵抗性

\begin{tabular}{|c|c|c|c|c|}
\hline \multirow{2}{*}{ 品種 } & \multicolumn{2}{|c|}{ 累積発病指数 } & \multirow{2}{*}{$\begin{array}{c}\text { 総合発病 } \\
\text { 指数 }\end{array}$} & \multirow{2}{*}{$\begin{array}{c}\text { 抵抗性 } \\
\text { 判定 }\end{array}$} \\
\hline & ポット検定 & 水耕検定 & & \\
\hline あまはづき & 0.0 & 0.5 & 0.3 & 強 \\
\hline こないしん & 4.2 & 13.3 & 8.7 & 強 \\
\hline からゆたか & 15.0 & 15.3 & 15.1 & やや強 \\
\hline ベにはるか & 12.8 & 24.8 & 18.8 & やや強 \\
\hline タマユタカ & 22.6 & 25.0 & 23.8 & 中 \\
\hline 高系 14 号 & 23.4 & 24.8 & 24.1 & 中 \\
\hline ベニアズマ & 20.2 & 28.5 & 24.4 & 中 \\
\hline コガネセンガン & 25.8 & 26.5 & 26.2 & やや弱 \\
\hline シロユタカ & 25.2 & 31.3 & 28.2 & 弱 \\
\hline ベニコマチ & 25.8 & 30.8 & 28.3 & 弱 \\
\hline
\end{tabular}

サッマイモつる割病の発病程度は, 指数 0 : 病徵なし〜指数 3 : 枯死の 4 段階で判定し, 調查期間 11 日間の指数の合計値を累積 発病指数とした。 また，ポット検定における累積発病指数と水 耕検定における累積発病指数の平均值を総合発病指数とした。

抵抗性判定は, 総合発病指数 10 未満を強, 10 以上 20 未満をや や強, 20 以上 25 未満を中, 25 以上 27 未満をやや弱, 27 以上 を弱とした。

りわずかに遅れ，「高系 14 号」，「タマユタカ」，「べには るか」がさらに遅れて枯死した. 一方,「からゆたか」と 「こないしん」は接種後 10 日間に扮いては茥や茎頂部が 枯死することはなかった。水耕検定に扣いても「あまは づき」は汪とんど病徵を示すことはなく，無施肥状態が 継続しても下葉がわずかに枯死したのみであった（図 2). 両検定について, 品種による病徴進展の遅速も考慮し て比較するために, 発病程度に応じて, 病徴なし（指数 0 ), 葉の黄変もしくは枯死（指数 1 ), 茥あるいは茎頂の 枯死（指数 2), 完全枯死（指数 3）のよ5に指数化し, 全調査期間の発病指数を加算して累積発病指数として数 值化すると，表1の通りとなった。「こないしん」，「べに はるか」,「ベニアズマ」に敃いて両検定間で累積発病指 数に 8 を超える比較的大きな差異を生じたが，概ね同様 な順番で抵抗性の品種間差が認められた。ささらに，両検 
定における累積発病指数の平均值として総合発病指数を 算出し, その数值により冬季温室検定に打り抵抗性を 判定すると，「あまはづき」と「こないしん」が強，「か らゆたか」と「ベにはるか」がやや強,「タマユタカ」, 「高系 14 号」，「ベニアズマ」が中，「コガネセンガン」が やや弱,「シロユタカ」と「ベニコマチ」が弱となった.

\section{2. 夏季試験}

夏季試験では，日射量と気温の上昇により生育が早ま
るため，比較的容易に大量の苗の調整が可能となる。そ こで，供試個体数を増やし，冬季試験で認められた抵抗 性の品種間差の有意性を検定した。 ポット検定，水耕検 定のいずれにおいても, 接種後 10 日目に抵抗性弱品種の 「ベニコマチ」が概ね完全枯死し，品種間で発病程度の差 が最も顕著となった。このため, 同日に病徵を調査し, 多重比較検定を実施した。 ポット検定および水耕検定の 結果を図 3 に示す。

供試した各品種の発病程度は,「ベニアズマ」で発病が

ポット検定，接種後10日目

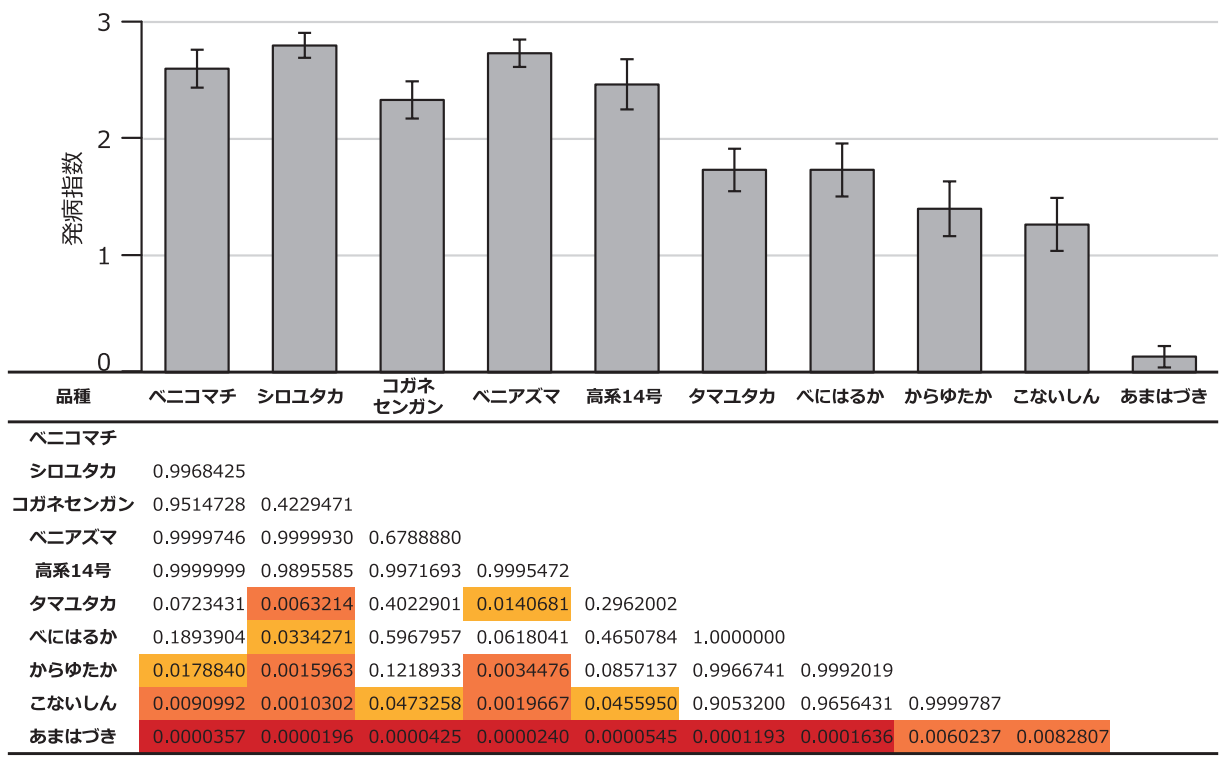

水耕検定，接種後10日目

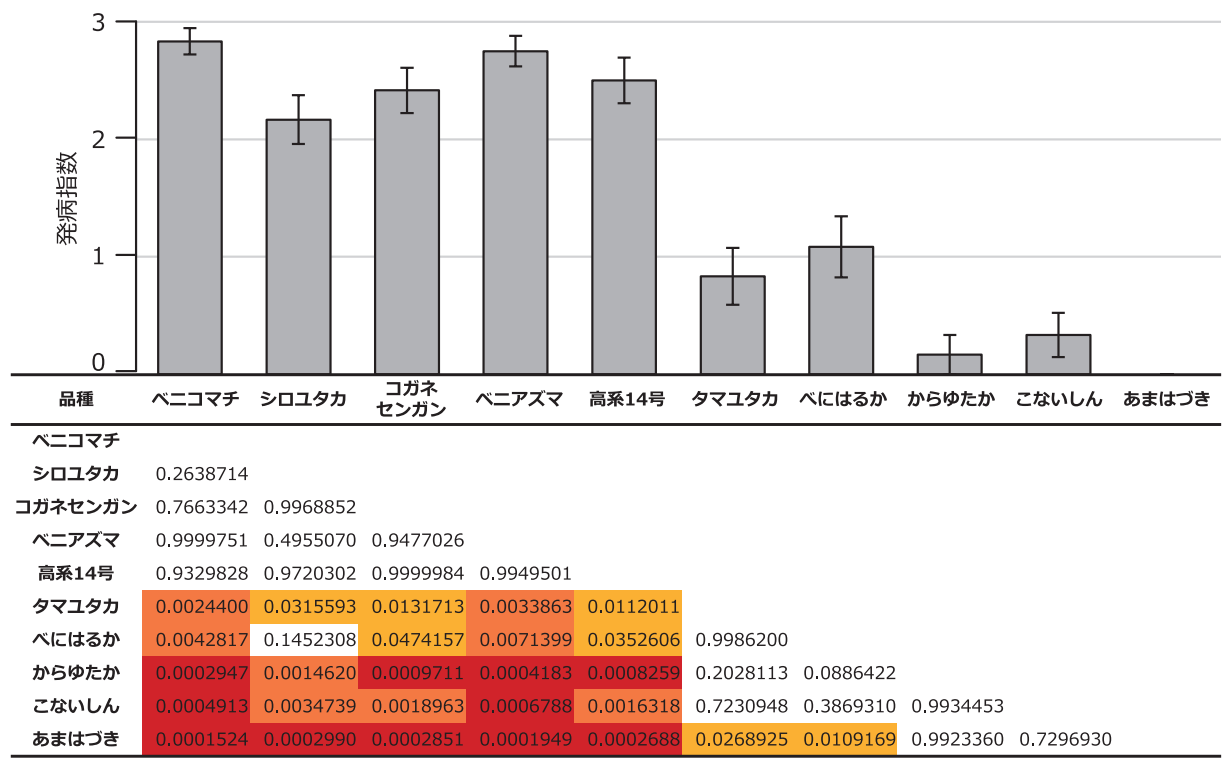

図 3. 夏季試験におけるサッマイモつる割病抵抗性の品種間の有意差検定結果.

上段：ポット検定に打ける接種後 10 日目の発病指数, 下段 : 水耕検定に打ける接種後 10 日目の発病指数.

グラフは 15 個体（ポット検定）抢よび 12 個体（水耕検定）の平均值士標準誤差を示す。表内の数値は, Steel-Dwass の多重比 較による各対比較における $P$ 值を示す。 $5 \%, 1 \%, 0.1 \%$ 水準で有意と判定された箇所を，それぞれ黄色，橙色，赤色で示した. 
表 2. 夏季試験検定結果から推定された各品種のサッマイモつ る割病抵抗性

\begin{tabular}{|c|c|c|c|c|}
\hline \multirow{2}{*}{ 品種 } & \multicolumn{2}{|c|}{ 接種後 10 日目の発病指数 } & \multirow{2}{*}{$\begin{array}{c}\text { 総合発病 } \\
\text { 指数 }\end{array}$} & \multirow{2}{*}{$\begin{array}{c}\text { 抵抗性 } \\
\text { 判定 }\end{array}$} \\
\hline & ポット検定 & 水耕検定 & & \\
\hline あまはづき & 0.1 & 0.0 & 0.1 & 強 \\
\hline こないしん & 1.3 & 0.3 & 0.8 & やや強 \\
\hline からゆたか & 1.4 & 0.2 & 0.8 & やや強 \\
\hline べにはるか & 1.7 & 1.1 & 1.4 & 中 \\
\hline タマユタカ & 1.7 & 0.8 & 1.3 & 中 \\
\hline 高系 14 号 & 2.5 & 2.5 & 2.5 & やや弱 \\
\hline ベニアズマ & 2.7 & 2.8 & 2.7 & 弱 \\
\hline コガネセンガン & 2.3 & 2.4 & 2.4 & やや弱 \\
\hline シロユタカ & 2.8 & 2.2 & 2.5 & やや弱 \\
\hline ベニコマチ & 2.6 & 2.8 & 2.7 & 弱 \\
\hline
\end{tabular}

サッマイモつる割病の発病程度は, 指数 0 : 病徴なし〜指数 3 : 枯死の 4 段階で判定し，供試した全個体の接種後 10 日目の指数 の平均值を発病指数とした。 また，ポット検定における発病指 数と水耕検定に打ける発病指数の平均值を総合発病指数とした. 抵抗性判定は, 総合発病指数 0.5 未満を強, 0.5 以上 1.0 未満を やや強, 1.0 以上 2.0 未満を中, 2.0 以上 2.6 未満をやや弱, 2.6 以上を弱とした。

多いことを除き，冬季試験に打ける結果と概ね一致した. ポット検定と水耕検定のいずれに扎いても，「あまはつ き」は「ベニコマチ」,「シロユタカ」,「コガネセンガン」, 「ベニアズマ」,「高系 14 号」,「タマユタカ」,「ベにはる か」と比べて少なくとも5\%水準で有意に発病が抑兄ら れた（図 3)。また「こないしん」は「ベニコマチ」,「シ ロユタカ」,「コガネセンガン」,「ベニアズマ」,「高系 14 号」と比べて少なくとも5\%水準で有意に発病が抑えら れた（図 3)。一方，サッマイモつる割病菌を含まない水 で苗浸漬した無接種無処理区では，ポット検定，水耕検 定ともに（各品種それぞれ 5 個体，4個体ずつ供試），葉 の黄変, 茎の枯死等のつる割れ病の病徵を示す個体は認 められず，供試苗はすべて健全であったものと推察され た。

両検定に打汀る発病指数の平均值として総合発病指数 を算出し，その数值により夏季試験に打ける抵抗性を判 定すると，「あまはづき」が強，「こないしん」と「から ゆたか」がやや強，「べにはるか」と「タマユタカ」が 中, 「高系 14 号」,「コガネセンガン」,「シロユタカ」が やや弱,「ベニアズマ」と「ベニコマチ」が弱となった（表2）.

\section{3. 圃場試験}

上記の温室における検定と同一の菌株を用いた戋場検 定（品種育成試験）の判定結果を表 3 亿示す。「あまはづ き」は 2018 年と 2020 年の 2 か年とも強,「タマユタカ」 は2 か年ともやや強,「べにはるか」は 2018 年が中, 2020 年がやや強であった。「高系 14 号」と「ベニアズマ」は 2 か年とも中，「コガネセンガン」と「シロユタカ」はい ずれも 2018 年がやや弱， 2020 年が中，「ベニコマチ」は 2 か年とも弱であった.
表 3. 圃場検定で評価された各品種のサッマイモつる割病抵抗性

\begin{tabular}{|c|c|c|c|c|}
\hline \multirow{2}{*}{ 品種 } & \multicolumn{2}{|c|}{2018 年 } & \multicolumn{2}{|c|}{2020 年 } \\
\hline & 発病指数 & 抵抗性判定 & 発病指数 & 抵抗性判定 \\
\hline あまはづき & 1.6 & 強 & 1.4 & 強 \\
\hline ベにはるか & 2.6 & 中 & 2.2 & やや強 \\
\hline タマユタカ & 2.3 & やや強 & 2.6 & やや強 \\
\hline 高系 14 号 & 3.4 & 中 & 3.1 & 中 \\
\hline ベニアズマ & 3.8 & 中 & 4.1 & 中 \\
\hline コガネセンガン & 4.7 & やや弱 & 3.4 & 中 \\
\hline シロユタカ & 5.1 & やp弱 & 4.4 & 中 \\
\hline ベニコマチ & 5.8 & 弱 & 5.7 & 弱 \\
\hline
\end{tabular}

サッマイモつる割病の発病指数は, $1:$ 無 6 : 枯死の 6 段階で 判定した.

抵抗性判定は, 2018 年は発病指数 1.7 未満を強, 1.7 以上 2.6 未 満をやや強, 2.6 以上 3.9 未満を中, 3.9 以上 5.2 未満をやや弱, 5.2 以上を弱とした。

2020 年は発病指数 1.8 未満を強, 1.8 以上 2.8 未満をやや強, 2.8 以上 4.5 未満を中, 4.5 以上 5.5 未満をやや弱, 5.5 以上を弱とし た。

\section{考察}

本研究では，近年育成された品種を含むサッマイモ 10 品種について，温室に执いてポット検定と水耕検定の両 方でサッマイモつる割病抵抗性を評価した。ポット検定 に抢ける接種条件等の方法は, 小川ら（1979）は $10^{8}$ 個/ $\mathrm{ml}$ の胞子懸濁液に苗の切り口を 30 秒浸漬したのに対し て, 本研究では多検体での操作性を考慮して $1.5 \times 10^{6}$ 個 $/ \mathrm{ml}$ の胞子懸濁液に 30 分浸漬する方法に改变して実施 した，一方，水耕検定では， $10^{7}$ 個 $/ \mathrm{ml}$ の胞子䯚濁液を苗 の茎中央部に針で接種した後水道水に插苗する方法（小 川ら 1988）や，苗を $10^{5}$ 個 $/ \mathrm{ml}$ の胞子懸濁液中に挿苗し てそのまま培養する方法 (Yang et al. 2018, Paul et al. 2020）が報告されているが，本研究では， $1.5 \times 10^{6}$ 個 $/ \mathrm{ml}$ の胞子懸濁液に 30 分浸漬した後, 水道水に挿苗する方法 を適用した。いずれの方法に抢いても接種後 5 日程度か ら葉や茎の枯死等の病徵が現れ，概视既報と合致する品 種間差が認められた。すなわち，小川ら（1979）の先行 研究によって抵抗性弱とされた「ベニコマチ」は，本研 究に扔いても抵抗性弱と判定されが，これまで抵抗性強 とされていた「タマユタカ」は，より強い抵抗性を示す 品種が存在したため, 中程度の抵抗性と位置付けられた。 一方，近年育成された「あまはづき」「てないしん」，「か らゆたか」や，作付面積が急速に増加している「べには るか」（甲斐ら 2017）は，それ年扎抵抗性が強，やや強 ～強, やや強, 中～やや強と判定され, 従来品種を上回 る抵抗性を有することが示唆された（表 1, 表 2)。これ らの結果は, 品種育成試験で実施されている國場検定の 結果（表3）ともよく一致して扣り，「あまはづき」や 「こないしん」が高い抵抗性を有することが, 複数の条件 において確認された。「べにはるか」については，別の先 行研究（堀田・高濱 2014）飞执いても抵抗性であると判 
定されている，特に強い抵抗性を示した「あまはづき」 と「こないしん」は，既存品種を超えるつる割病抵抗性 を有する品種としての作付けが期待できるだけでなく， 今後の病害抵抗性サッマイモ品種開発に拈ける重要な育 種素材であると考兄られる。

本研究で実施したポット検定法扔よび水耕検定法は, 気象条件の変動の影響を受けにくく，健全な苗を調整で きれば冬季にも実施可能であり, 抵抗性判定結果が品種 育成試験で年 1 回実施される戋場検定のものとよく一致 したため, 圃場検定を補完する検定方法として活用可能 と考学られる。これらの検定に打いては，病原菌を接種 した苗を培土あるいは水に扱苗した直後の温度管理に留 意する必要がある。秋〜冬の温室で継代により栽培され る苗は，春〜夏に種いもから萌芽する苗と比べて苗質が 劣るため, 植兄付け直後の高温と乾燥の影響をらけて萎 调しやすい, このため, 接種直後の温度管理に特段の注 意を要する，温室の天空，側空を開放する等，過度の高 温への暴露を回避する。しかしながら，ポット検定では， 接種苗の植え付け直後に高温に暴露されて葉が激しく萎 调した場合においても，「あまはづき」，「こないしん」， 「べにはるか」では，供試した 5 本の苗すべてが接種後 16 日目に沶いて枯死せずと生存した結果が得られてい る. 冬季試験と夏季試験の結果を比較すると, 夏季試験 に扔いて「ベニアズマ」の発病が増えているが，供試し た苗が徒長して苗質が低下したためと考兄られる。夏季 試験では生育が早いため, 品種によっては苗が徒長しや すい, このため, 供試苗を増殖する際に挿苗の時期をず らすことによって，供試品種間で苗の生育状態をそろえ ることに留意する必要がある。ポット検定と水耕検定の 2 つの検定法を比較すると, ポッ卜検定法のほうが病徵 の進展が穏やかであるため（図 1)，発病途中段階に打い ても正確な抵抗性強弱判定が可能である。また，上記の 通り高温に暴露された場合に㨟いても品種間差を評価し らる。このため, より多くの検体の検定にはポット検定 法のほうが適すると判断する.

また，本研究では抵抗性強弱の判定指標として，冬季 試験（表 1）では 11 日間の指数の合計である累積発病指 数を用い, 夏季試験（表 2) では接種後 10 日目の指数の 平均值である発病指数を用いて抢り, 計算方法が異なる. 冬季は苗数の確保が難しい. 供試苗数が少ないと, 特定 の一日の発病指数だけでは品種間差が現れにくいため, 累積発病指数を用いた。累積発病指数を用いることで, 苗数を十分に確保した夏季試験の特定の一日の発病指数 を使った場合とほぼ同様の判定結果を得ることができた ため, 供試苗数が少ない場合は, 累積発病指数の適用が 有効と考穴られる.

本研究では茨城県行方市で採取された 16NGFo1 株を 用いて検定したが，今後他の産地で被害が発生した場合， 現地で分離された菌株についても同様の方法で迅速に検 定を実施することが可能である。また，近年，検定に労
力を要するサッマイモネコブセンチュウ抵抗性について, 抵抗性の異なる 2 品種を交配して作成した $\mathrm{F}_{1}$ 集団の量的 形質遺伝子座 (QTL) 解析により DNA マーカーを作成 する試みが開始されている（Sasai et al. 2019）。このよう な DNA マーカーを作成する際の多検体の抵抗性評価を 反復して実施する場面に㨟いても, 本研究の温室内検定 法は有効々考光られる. 我々は最近, 次世代シーケンス 技術を用いて，いも類等同質倍数体作物に沶いて DNA マーカーを迅速に開発する polyploid QTL-seq 法を開発し た（Yamakawa et al. 2021）。今後は, 本検定方法を活用し てサッマイモつる割病抵抗性 DNA マーカー開発を進め たい.

\section{謝 辞}

本研究は農林水産省国際競争力強化技術開発プロジェ クト「輸出促進のための新技術・新品種開発」(事業実施 主体：農研機構）の支援を受けて実施された。また，実 施にあたり, 農研機構次世代作物開発研究センターの羽 鹿牧太氏 (現東北農業研究センター), 田口和憲氏 (現中 日本農業研究センター), 九州沖縄農業研究センターの小 林晃氏，小林有紀氏，ならびに遺伝資源センターの青木 孝之氏にサッマイモつる割病菌について貴重な御助言を いただいた。菌検体調製においては，機器等で農研機構 生物機能利用研究部門の瀬尾茂美氏，光原一朗氏飞御支 援をいただいた。温室および國場試験の実施に際し，農 研機構技術支援部中央技術支援センターつくば第 3 業務 科谷和原畑作技術チームの科員の各位にご協力いただい た.ここに記して深謝の意を表する.

\section{引用文献}

堀田治邦・高濱雅幹（2014）北日本病虫研報 65: 32-36.

甲斐由美・境 哲文・片山健二・熊谷 亨・石黑浩二・中澤芳 則・山川 理・吉永 優 (2017) 農研機構研報九州沖縄農 研 66: 87-119.

Katayama, K., A. Kobayashi, T. Sakai, T. Kuranouchi and Y. Kai (2017) Breed. Sci. 67: 3-14.

農林水産省地域作物課（2019）いも・でん粉に関する資料. 農 林水産省.

小川 奎（1988）農研センター研報 10: 1-125.

小川 奎・竹股知久 - 竹内昭士郎・駒田 旦・安藤隆夫 (1979) 農事試研報 30: 97-120.

Paul, N.C., W. Park, S. Lee, M.N. Chung, H.U. Lee and J.W. Yang (2020) Plants 9: 497.

Sasai, R., H. Tabuchi, K. Shirasawa, K. Kishimoto, S. Sato, Y. Okada, A. Kuramoto, A. Kobayashi, S. Isobe, M. Tahara et al. (2019) DNA Res. 26: 399-409.

島田 峻 - 赤井浩太郎 - 西宮智美 - 渡邊 健 - 有江 力 (2017) 日植病報 83: 211 .

Yamakawa, H., E. Haque, M. Tanaka, H. Takagi, K. Asano, E. Shimosaka, K. Akai, S. Okamoto, K. Katayama and S. Tamiya (2021) Plant Biotechnol. J. 19: 2040-2051.

Yang, Z., Y. Lin, H. Chen, W. Zou, S. Wang, Q. Guo and X. Chen (2018) Crop Sci. 58: 1558-1565. 